\title{
Maconellicoccus hirsutus (Green) Register in Teak Forest Santds in the Mato Grosso State, Brazil
}

\author{
Otávio Peres-Filho', Yair Ben-Dov², Vera Regina dos Santos Wolff ${ }^{3}$, \\ Alberto Dorval ${ }^{1}$, Marcelo Dias de Souza ${ }^{4}$ \\ ${ }^{1}$ Programa de Pós-graduação em Ciências Florestais e Ambientais, Universidade Federal de Mato Grosso - UFMT, \\ Cuiabá/MT, Brasil \\ ${ }^{2}$ Department of Entomology, Agricultural Research Organization, The Volcani Center, Bet Dagan, Israel \\ ${ }^{3}$ Fundação Estadual de Pesquisa Agropecuária - FEPAGRO, Porto Alegre/RS, Brasil \\ ${ }^{4}$ Programa de Pós-graduação em Ciências Ambientais, Universidade de Cuiabá - UNIC, Cuiabá/MT, Brasil
}

\begin{abstract}
The pink hibiscus mealybug, Maconellicoccus hirsutus Green (Hemiptera, Pseudococcidae) is registered for the first time in teak forest stands, Tectona grandis, in the municipality of São José de Quatro Marcos, State of Mato Grosso, Brazil. Information on the geographical distribution, biology, damage and management of this pest is provided.
\end{abstract}

Keywords: pink hibiscus mealybug, exotic pest, Tectona grandis.

The pink hibiscus mealybug, Maconellicoccus hirsutus (Green) (here abbreviated PHM) (Hemiptera, Pseudococcidae), supposedly of origin in Southeast Asia, is currently widely-distributed in the Afrotropical, Australasia, North America, Central America, South America, Caribbean region, Oceania and the Palaearctic regions (Ben-Dov et al., 2014). In Brazil, it was first registered at the municipalities of Bonfim, Paracaima and at Boa Vista, in the State of Roraima (Culik et al., 2013; Marsaro et al., 2013).

The PHM is highly-polyphagous and was recorded from about 330 plant species that include trees and shrub of economic importance (Williams, 1985; Williams \& Willink, 1992; Ben-Dov et al., 2014). The objective of this study is to record the occurrence of M. hirsutus in teak stands and also to assess the damage caused by this pest.

The PHM was collected in November 6, 2013 at two plantations of Tectona grandis Linn. f. (Lamiaceae), in the municipality of São José de Quatro Marcos, State

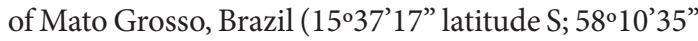
longitude W). The two areas hold a total of 1,300 ha planted with teak, the area infested in the first property (four years) had about 189 ha, and the second one (six years), about 107 ha.

Sampling was simple random, and five plots were selected for the two areas. Each plot contained $400 \mathrm{~m}^{2}$ $(20 \mathrm{~m} \times 20 \mathrm{~m}$ ) of area, with a $50 \mathrm{~m}$ distance from the edge of the plot. In the first plantation three locations were inspected and at the second property only two, totalizing five plots. In each plot, approximately 40 trees were investigated, and their trunk, branches, leaves and needles analyzed.

The collected material was placed in plastic bags and taken for further study to the Forest Protection laboratory of Forest Engineering College, Federal University of Mato Grosso. The separation of the mealybugs from the plant material was performed by flushing the infested plant material with alcohol $70 \%$, 
then, separating then with brush and preserved in $70 \%$ alcohol in glass tubes.

The mealybugs were identified by one of the authors (YBD). The specimens were stored in LAPROFLOR and Department of Entomology, Agricultural Research Organization, The Volcani Center, Israel.

The collected material was identified as M. hirsutus. At the first inspected property (plot 1) $100 \%$ of the trunks and crowns were infested (Figure 1A). At plot $2,95 \%$ of infestation was recorded on trunks and $100 \%$ on crowns, and at plot 3, 20\% of infestation on trunks and $100 \%$ on crowns. In the second property, the two inspected plots, were found to be $100 \%$ of infested in the trunks and crowns, and the infested trees were clearly distinguished in reduced twig growth in the crowns, and remarkable drop of leaves (Figure 1B).

The occurrence of M. hirsutus in Central America was first reported from the Caribbean Island in Grenada in teak stands and Hibiscus trees (Pollard, 1995). Kairo et al. (2000) suggested that the PHM was accidentally introduced into the Caribbean in the early 1990s.

It was reported in 1994. After that, it spread quickly to Caribbean countries, becoming one of the most important pest species. Tambasco et al. (2000) have already indicated that $M$. hirsutus might spread into Brazil because of its presence in South America and the favourable environmental conditions. Eventually it was confirmed by Marsaro et al. (2013) who registered it for the first time in the State of Roraima, Brazil, in the year
2010, on the following nine host-plants, Annona muricata L. (Annonaceae), Glycine max (L.) Merr. (Fabaceae), Centrolobium paraensis Tul. (Fabaceae), Inga edulis Mart. (Fabaceae), Hibiscus rosa-sinensis L. (Malvaceae), Psidium guajava L. (Myrtaceae), Averrhoa carambola L. (Oxalidaceae), Citrus sinensis (L.) (Rutaceae) and Solanum lycopersicum L. (Solanaceae). Also according to the authors, the species $C$. paraensis, I. edulis and C. sinensis are registered for the first time as a host.

Culik et al. (2013) registered M. hirsutus also from the Espírito Santo State, Brazil (which is $3400 \mathrm{~km}$ southeastern of Roraima) on plants of Okra, Abelmoschus esculentus. Also, according to the authors, this insect is established in Espírito Santo and may become widely established in South America, because M. hirsutus is a potential pest plant in theseregions and nearby. Agricultural management methods may need to be modified because of its presence.

Maconellicoccus hirsutus is a highly-polyphagous mealybugs that attacks some forest plants that has economic importance, such as Hibiscus elatus, Samanea saman, Gliricidia spp. and teak. Assuming that these plant species are highly-susceptible to this pest, it can lead to death plant in case of a high infestation (Sagarra \& Peterkin, 1999).

The chemicals commonly used to control pink mealybug have limited effectiveness, due to the habit of settling in cracks on the bark and for presenting the body coated with wax (Williams, 1986). Sprays with mineral oils showed good results in guava (Mani, 1989).
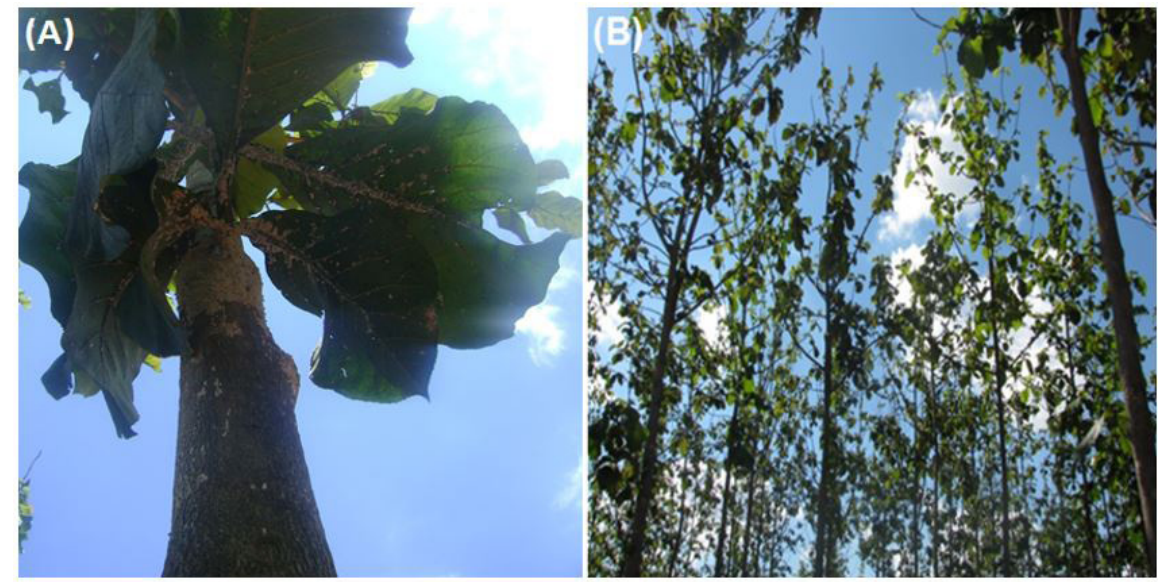

Figure 1. Maconellicoccus hirsutus infestation in teak stands, Tectona grandis, at São José de Quatro Marcos, MT, Brazil, 2013. (A) Detail of infested trunk at locality 1. (B) Crowns of trees infested with a reduced amount of leaves. 
The biological control with ladybirds Cryptolaemus montrouzieri Mulsant (Coleoptera, Coccinellidae) is an efficient method to control pink mealybug in India (Mani \& Krishnamoorthy, 2008) and in Caribe (Kairo et al., 2000). In Egito, C. montrouzieri was unable to survive the harsh winter of the region and did not show satisfactory results, even though the principal agents of biological control were the parasitoids Anagyrus kamali Moursi and Achrysopophagus sp. (Hymenoptera, Encyrtidae) (Bartlett, 1978). Anagyrus kamali was also introduced in the Caribbean, to control of $M$. hirsutus. However, the success of the biological control program in the Caribbean can be attributed to the rapid rate of reproduction and to public awareness programs on the reduction of pest control chemicals (Kairo et al., 2000).

\section{SUBMISSION STATUS}

Received: 19 july 2016

Accepted: 9 oct., 2016

\section{CORRESPONDENCE TO}

\section{Marcelo Dias de Souza}

Programa de Pós-graduação em Ciências Ambientais, Universidade de Cuiabá - UNIC, Rua Barão de Melgaço, 222, CEP 78005-300, Cuiabá, MT, Brasil

e-mail: marcelo.dias@florestal.eng.br

\section{REFERENCES}

Bartlett BR. Pseudococcidae. In: Clausen CP, editor. Introduced parasites and predators of arthropod pests and weeds: a world review. Washington: USDA; 1978.

Ben-Dov Y, Miller DR, Gibson GAP. ScaleNet, Maconellicoccus hirsutus [online] 2014. [cited 2015 June 27]. Available from: http://www.sel.barc.usda.gov/scalenet/archive/ sep2014_Pseudococcidae.htm
Culik MP, Martins DS, Zanuncio JS Jr, Fornazier MJ, Ventura JA, Peronti ALBG et al. The invasive hibiscius mealybug Maconellicoccus hirsutus (Hemiptera: Pseudococcidae) and its recent range expansion in Brazil. The Florida Entomologist 2013; 96(2): 638-640. http:// dx.doi.org/10.1653/024.096.0234.

Kairo MTK, Pollard GV, Peterkin DD, Lopez VF. Biological control of the hibiscus mealybug Maconellicoccus hirsutus Green (Homoptera: Pseudococcidae) in the Caribbean. Integrated Pest Management Reviews 2000; 5(1): 241-254. http://dx.doi.org/10.1023/A:1012997619132.

Mani M, Krishnamoorthy A. Field efficacy of Australian ladybird beetle Cryptolaemus montrouzieri Mulsant in the suppression of Maconellicoccus hirsutus (Green) on sapota. Journal of Biological Control 2008; 22(1): 471-473.

Mani M. A review of the pink mealybug - Maconellicoccus hirsutus. Insect Science and Its Application 1989; 10(1): 157-167.

Marsaro AL Jr, Peronti A, Penteado-Dias AM, Morais EGF, Pereira PRVS. First report of Maconellicoccus hirsutus (Green, 1908) (Hemiptera: Coccoidea: Pseudococcidae) and the associated parasitoid Anagyrus kamali Moursi, 1948 (Hymenoptera: Encyrtidae), in Brazil. Brazilian Journal of Biology 2013; 13(2): 413-418. PMid:23917571. http://dx.doi.org/10.1590/S1519-69842013000200024.

Pollard GV. Pink or hibiscus mealybug in the Caribbean. Caraphin News 1995; 12(1): 1-2.

Sagarra LA, Peterkin DD. Invasion of the Caribbean by the hibiscus mealybug, Maconellicoccus hirsutus Green (Homoptera: Pseudococcidae). Phytoprotection 1999; 80(2): 1999. http://dx.doi.org/10.7202/706185ar.

Tambasco FJ, Sá LAN, Nardo EAB, Tavares MT. Cochonilha rosada Maconellicoccus hirsutus (Green): Uma praga de importância quarentenária já se encontra na Guiana Inglesa. Floresta 2000; 30(1-2): 85-93.

Williams DJ, Willink MCG. Mealybugs of Central and South America. London: CAB International; 1992.635 p.

Williams DJ. Australian mealybug. London: British Museum (Natural History); 1985. 953 p.

Williams DJ. The identify and distribution of the genus Maconellicoccus Ezzat (Hemiptera, Pseudococcidae) in Africa. Bulletin of Entomological Research 1986; 7(1): 351-357. http://dx.doi.org/10.1017/S0007485300014814. 